УДК 316.6

\title{
СОЦИАЛЬНОЕ САМООПРЕДЕЛЕНИЕ МОЛОДЕЖИ БУРЯТИИ (ЦЕННОСТНЫЙ АСПЕКТ)
}

\author{
Русанова Анна Алексеевна \\ кандидат педагогических наук, доцент \\ заведующая кафедрой социологии \\ Лаврикова Виктория Николаевна \\ кандидат социологических наук \\ доцент кафедры социологии \\ Филиппова Елена Владимировна \\ старший преподаватель кафедры социологии \\ ФГБОУ ВО «Забайкальский \\ государственный университет»
}

Аннотация: В статье раскрывается ценностный аспект социального самоопределения молодежи Бурятии на материалах социологического исследования, выполненного при финансовой поддержке РФФИ и ЭИСИ в рамках научного проекта № 21-011-31524.

Авторы раскрывают структуру социального самоопределения, условия протекания этого процесса. Основной акцент делается на зависимости характера социального самоопределения молодежи от ценностно-смысловой сферы личности.

Ключевые слова: Социальное самоопределение, ценности, ценностносмысловая сфера личности.

\section{SOCIAL SELF-DETERMINATION OF THE YOUTH OF BURYATIA (VALUE ASPECT)}

Rusanova Anna Alekseevna Lavrikova Victoria Nikolaevna Filippova Elena Vladimirovna 
Abstract: The article reveals the value aspect of the social self-determination of the youth of Buryatia based on the materials of a sociological study carried out with the financial support of the RFBR and EIS within the framework of the scientific project No. 21-011-31524.

The authors reveal the structure of social self-determination, the conditions of this process. The main emphasis is placed on the dependence of the nature of social self-determination of youth on the value-semantic sphere of personality.

Key words: Social self-determination, values, value-semantic sphere of personality.

Проблемы общественного развития невозможно рассматривать никак иначе, как только в опоре на совокупность всех процессов, которые происходят с человеком, поколением, конкретным обществом и всем человечеством. Молодежь, как социально-значимая часть общества по целому ряду показателей (социально-трудовая и политическая активность, культурные ориентиры, воспроизводство рабочей силы, качественная составляющая населения общества и др.), всегда на острие проблем. Потому велик научный интерес к этой социально-демографической группе, ее социальному статусу, функциям, роли в обществе, который проявлялся на всем протяжении ее существования [1].

Все процессы, происходящие в обществе, оказывают непосредственное или опосредованное влияние на самоопределение молодежи в этом обществе: получение образования, приобретение социального статуса, выбор профессии, поиск работы и т.д. всегда сопряжены с реалиями общественного развития [2].

Сама по себе категория самоопределения является неоднозначной по своей сути. Вопросы самоопределения изучаются в рамках многих научных подходов, в частности, субъектного (К.А. Абульханова-Славская, С.Л. Рубинштейн), типологического (Б.С. Братусь, Л.Н. Гумилев, Э. Фромм, Э. Шпрангер, К.Г. Юнг); личностного (Л.И. Божович, М.Р. Гинзбург, И.Кон) и др. Выбранный авторами ракурс рассмотрения процесса социального самоопределения молодежи вписывается в контекст общей теории социализации (Ф. Гиддингс, Э. Дюркгейм, Г. Зиммель, Р. Мертон, Т. Парсонс, Г. Тард) и теорий идентичности (Дж. Мид, Э. Гофман, Э. Эриксон) [3]. 
Как многомерное явление и понятие молодежь рассматривается в работах Н.М. Блинова, В.Н. Боряза, Ю.Е. Волкова, И.М. Ильинского, С.Н. Иконниковой, В.Т. Лисовского, И.С. Кона, А.С. Капто, В.А. Мансурова, В.И. Н.Л. Смакотиной, Чупрова и др. Проблемы социализационных процессов в молодежной среде являются предметом исследований Б.Г. Ананьева, Г.И. Гилинского, Ю.Н. Давыдова, Ю.А. Зубок, С.Н. Иконниковой, И.С. Кона, Б.Д. Парыгина, В.Я. Титаренко, О.И. Шкаратана, В.Н. Шубкина и др.

Данные методологические аспекты легли в основу эмпирического исследования по выявлению особенностей социального самоопределения молодежи Бурятии, проведенного авторами в ноябре - декабре 2021 года.

Методика проведения: онлайн-опрос с применением технологии таргетирования.

Инструментарий опроса - анкета, вопросы которой структурированы в блоки в опоре на авторское видение структуры социального самоопределения:

- социально-профессиональное самоопределение, т.е. определение себя относительно выработанных в обществе (и принятых данным человеком) критериев профессионализма $\mathrm{c}$ целью достижения профессиональной идентификации;

- социально-политическое самоопределение, т.е. определение себя относительно гражданских и политических институтов общества с целью выделения и обоснования собственной гражданской и политической позиции;

- социокультурное самоопределение, т.е. определение себя относительно человеческих ценностей с целью выделения и обоснования собственной жизненной концепции [4].

В опросе приняли участие 798 молодых людей в возрасте от 14 до 35 лет, работающие и неработающие (учащиеся, студенты, безработные и т.д.) $-49,8 \%$ и $50,2 \%$, соответственно.

В данной статье остановимся лишь на одном аспекте социального самоопределения молодых жителей Бурятии - ценностном, т.к. ценностносмысловая сфера личности является базовым основанием социального самоопределения.

В целом, можно говорить, что доминирующими у молодежи Бурятии являются терминальные ценности: в ТОП-3 вошли семья $(81,1 \%)$, любовь (52,6\%) и дружба (47\%). Хотя, ярко выражена и прагматическая ориентация: 
деньги как ценность так же находится в верхней позиции рейтинга ценностей (44\%). Далее в рейтинге следуют ценности, отражающие стереотипы мышления в достижении жизненного успеха: свобода (42\%), самореализация (37,2\%), справедливость (36,5\%). Альтруизм и духовность присущи совсем незначительной части молодых людей: совесть, милосердие, служение обществу заняли последние позиции рейтинга ценностей.

При всей ценности семьи, лишь для 6,4\% опрошенных молодых людей является неприемлемым незарегистрированный брак (сожительство), а 9,2\% относятся отрицательно к такому типу семьи.

Ориентация на традиционные ценности прослеживается и в выборе большинством респондентов позиции «нет, ни при каких обстоятельствах», когда им было предложено определить для себя возможность/невозможность вступить в брак по расчету $(66,7 \%)$, вступить в физическую близость за плату $(86,3 \%)$, взять то, что плохо лежит, взять силой $(77,7)$, употребление наркотиков $(92,3 \%))$, уклонение от налогов $(83,5 \%)$, получение (дачу) взятки $(82,5 \%)$. А вот употребление нецензурных выражений и употребление спиртных напитков в равной степени как приемлемо, так и не приемлемо для молодых людей.

Большинство опрошенных отрицательно относятся и к таким явлениям нашей жизни как национализм, экстремизм, незаконное обогащение, нарушение правопорядка и т.д. Но карьеризм не вызывает особого негатива у молодежи, что вполне объяснимо с точки зрения современных взглядов на продвижения по карьерной лестнице.

Полученные результаты достаточно ярко демонстрируют парадоксальность и неопределенность ценностных ориентаций молодежи Бурятии, что подтверждается, на наш взгляд, и ответами на вопрос «Что из перечисленного Вам приходилось безвозмездно делать за последний год для других людей (не членов семьи и не близких родственников)?». Большинство (57\%) оказывали эмоциональную поддержку, давали житейские советы; почти каждый третий помогал деньгами (в долг и безвозмездно), продуктами и вещами, оказывал бытовую и физическую помощь. При этом, коллективнополезная деятельность на благо общества, своего местного или территориального сообщества не пользуется интересом в молодежной среде. 


\section{ПЕРЕДОВОЕ РАЗВИТИЕ СОВРЕМЕННОЙ НАУКИ:

Интересные результаты были получены в ответах на вопрос о самоидентификации, когда респондентам предлагалось осмыслить свою принадлежность к определенной социальной конструкции (Таблица 1). В ТОП-3 вошли: житель Бурятии - 23,3, россиянин - 16,3\% сын/дочь - 16,1. Как видим, большая часть отвечавших на этот вопрос осознает и гордится своей принадлежностью к жителям Бурятии. В сознании молодых людей наиболее актуальной является близость с территорией проживания (мезосреда), в равной мере - близость личного характера (микросреда) и общечеловеческая близость (макросреда).

Таблица 1

Распределение ответов респондентов на вопрос:

Кем Вы себя осознаете, принадлежностью к кому гордитесь?

\begin{tabular}{|l|c|}
\hline \multicolumn{1}{|c|}{ позиция } & проценты \\
\hline Россиянином & 16,3 \\
\hline Сибиряком & 6,4 \\
\hline Жителем Бурятии & 23,3 \\
\hline Человеком своего поколения & 10,6 \\
\hline Специалистом в своем деле & 6,2 \\
\hline Верующим человеком & 3,6 \\
\hline Хозяином своего дома & 2,4 \\
\hline Сыном/дочерью своих родителей & 16,1 \\
\hline Женщиной/мужчиной & 6,4 \\
\hline Другое (напишите) & 1,3 \\
\hline Затрудняюсь ответить & 7,4 \\
\hline
\end{tabular}

Логично было бы предположить, что определенная часть молодежи удовлетворена жизнью в Бурятии. Но на самом деле, были получены несколько иные результаты: большинство молодых людей не довольны положением дел в своем регионе $(57,7 \%$ - в совокупности позиций «безусловно, не доволен» и «не доволен» при 17,1\% - затруднившихся ответить) (Таблица 2); 33,9\% респондентов оценивают возможности молодежи для ее самореализации в своем регионе как плохие (Таблица 3); а $80,9 \%$ (в совокупности) - хотели бы уехать на постоянное место жительства в другой регион по той или иной причине (Таблица 4). 
Таблица 2

Распределение ответов респондентов на вопрос: Если говорить в целом, Вы довольны или недовольны положением дел в Вашем регионе?

\begin{tabular}{|l|c|}
\hline \multicolumn{1}{|c|}{ Вариант ответа } & проценты \\
\hline Безусловно доволен & 5,4 \\
\hline Скорее доволен & 19,9 \\
\hline Скорее не доволен & 40,6 \\
\hline Безусловно не доволен & 17,6 \\
\hline Затрудняюсь ответить & 17,1 \\
\hline
\end{tabular}

Таблица 3

Распределение ответов респондентов на вопрос: Как Вы оцениваете возможности молодежи для ее самореализации в Вашем регионе?

\begin{tabular}{|l|c|}
\hline \multicolumn{1}{|c|}{ Вариант ответа } & проценты \\
\hline Хорошие & 12,4 \\
\hline Средние & 43,6 \\
\hline Плохие & 33,9 \\
\hline Затрудняюсь ответить & 10,0 \\
\hline
\end{tabular}

Таблица 4

Распределение ответов респондентов на вопрос: Хотели бы Вы уехать на постоянное место жительства в другой регион?

Если собираетесь уехать, то с какой целью?

\begin{tabular}{|l|c|}
\hline \multicolumn{1}{|c|}{ Вариант ответа } & проценты \\
\hline Да, с целью получения более качественного образования & $\mathbf{1 4 , 3}$ \\
\hline $\begin{array}{l}\text { Да, с целью получения более престижной должности или высоко } \\
\text { оплачиваемой работы }\end{array}$ & $\mathbf{2 8 , 3}$ \\
\hline Да, с целью улучшения жилищных проблем & $\mathbf{8 , 0}$ \\
\hline $\begin{array}{l}\text { Да, с целью получения больших возможностей для развлечений и } \\
\text { отдыха }\end{array}$ & $\mathbf{5 , 6}$ \\
\hline Да, просто не хочу здесь жить & $\mathbf{9 , 2}$ \\
\hline Да, не подходит климат & $\mathbf{1 4 , 3}$ \\
\hline Нет, но есть такие мысли & $\mathbf{1 6 , 7}$ \\
\hline Нет, и не планирую & $\mathbf{9 , 0}$ \\
\hline Затрудняюсь ответить & $\mathbf{0 , 2}$ \\
\hline
\end{tabular}


Данные результаты демонстрируют не только проблемы региона (низкие зарплаты, качество образования, проблемы с жильем и рекреативной сферой), но и позволяют задуматься о миграционных настроениях молодых жителей Бурятии. По сути, молодежь не хочет решать проблемы в своем регионе, а предпочитает бежать от них в поисках лучшей жизни, ориентируясь на стереотипы западного толка по типу «все и сразу». Разочарование, неверие в свою значимость и пассивность латентно присутствуют в ответах на вопрос об участии в выборах: $45,2 \%$ респондентов в качестве причины низкого участия молодежи в выборном процессе определяют не возможность на что-то повлиять и что-либо реально изменить.

Таким образом, анализ результатов опроса позволили выделить две группы ценностных ориентаций и установок молодежи Бурятии: первая ориентации на традиционные моральные и гражданские ценности, вторая ориентации на ценности «нового» общества, на стереотипы мышления западного толка. Все это позволяет говорить о неопределенности и противоречивости социального самоопределения молодых людей, проживающих на территории Бурятии.

В 2018 году Республика Бурятия вошла в состав Дальневосточного федерального округа (ДФО), став участником федеральной программы устойчивого развития. Появилась надежда, что это событие станет поворотным в жизни региона с точки зрения формирования новых социальноэкономических, социально-политических и социокультурных условий социального самоопределения молодежи. Но сама молодежь Бурятии пока не испытывает в этом плане особого оптимизма: 43,2\% затруднились оценить появление новых возможностей для нее в связи с вхождением в ДФО.

\section{Список литературы}

1. Павловский В. В. Социально-философские основания исследования молодежи : Автореф. дисс. ... докт. философ. н. - Новосибирск, 1999. - 38 с.

2. Левичева В.Ф. Социальное самоопределение молодежи // Энциклопедия гуманитарных наук. - №2. - 2012. - С.322-324.

3. Безруков А.В. Социальное самоопределение молодежи в современном российском обществе: Дисс...канд.социол.н. Пермь, 2021. 237 с. 
4. Русанова А.А. Социальное самоопределение современной студенческой молодежи в условиях социальной неопределенности - Чита:ЗАБГУ. 2015. - 315c.

(C) А.А. Русанова, В.Н. Лаврикова, Е.В. Филиппова, 2021 